\title{
Organics Characteristics of Sludge from a Full-Scale Anaerobic Digester Treating Domestic Mixed Sewage Sludge
}

\author{
Roslinda Seswoya ${ }^{1, *}$, and Ahmad Tarmizi Abdul Karim ${ }^{1}$ \\ ${ }^{1}$ Micropollutant Research Centre, Faculty of Civil and Environmental Engineering, Universiti Tun \\ Hussein Onn Malaysia, Parit Raja, Johor.
}

\begin{abstract}
Sewage sludge, normally in form of mixed sewage sludge is treated using anaerobic digester worldwide. In Malaysia, sewage sludge was categorized as domestic sewage sludge since sewage treatment plant treats only domestic sewage. The complex organic compounds in form of carbohydrates and proteins are transformed to methane during anaerobic digestion. The characteristics of complex organic compounds in domestic mixed sewage sludge are needed to assess the energy recovery form digesting domestic mixed sewage sludge. Besides that, it is common to use anaerobic biomass from existing anaerobic digester for the new setup of the anaerobic reactor. Therefore, this study was outlined to study the characteristics of domestic mixed sewage sludge and anaerobic biomass, particularly on the complex organic compounds. The complex organic compounds measured were carbohydrates and proteins. The higher complex organic solubilisation as a result of thermal pre-treatment was proven to improve the methane production. Therefore, in this study, the impact of low thermal pre-treatment in improving the organics solubilisation was assessed too. Low thermal pre-treatment at $70^{\circ} \mathrm{C}$ and $90^{\circ} \mathrm{C}$ at various treatment time were applied to the domestic mixed sewage sludge. The results indicated that the domestic sewage sludge and anaerobic biomass from a full-scale anaerobic digester contained complex organic compounds; existed mostly in form of particulate as shown by the low value of soluble to total ratio. Besides that, the low thermal treatment at $70^{\circ} \mathrm{C}$ and $90^{\circ} \mathrm{C}$ increased the organics solubilisation. Protein solubilisation was observed exceeded $8 \%$ after being treated for $20 \mathrm{~min}$ at both thermal treatments. However, the impact of low thermal treatment was better at $90^{\circ} \mathrm{C}$, in which higher solubilisation was observed at longer treatment time.
\end{abstract}

\section{Introduction}

Anaerobic digestion is a biological process to degrade the organic pollution with the existence of several types of anaerobic microorganisms, in which the biogas is produced. The biogas has a high calorific value and is considered as a renewable energy source [1].

* Corresponding author: roslinda@uthm.edu,my 
The airtight tanks are used for anaerobic digestion. Many types of the organic material can be digested, except for stable woody materials. The lignin in the stable wood is hard to be degraded by the anaerobic micro-organisms lignin [1]. Substrate to anaerobic digester varies including landfill leachate, and sewage sludge [2], [3].

Asia Pacific Economic Cooperation (APEC) economies (including Malaysia) have made commitments to promote renewable power generation and have implemented a variety of policies to support wider adoption of renewable technologies [4]. This energy policy will shape the region's' energy future. According to Kumaran [5], if entire sewerage system in Malaysia adopts anaerobic digestion, the methane (renewable energy) from sewage sludge is estimated as $1,132,512.50 \mathrm{~m}^{3} \mathrm{CH}_{4}$ /day and the energy production is 4.75 GW.h/day. Unfortunately, only few sewage treatment in Malaysia adopting the anaerobic digestion. Anaerobic digester in Jelutong Sewage Treatment Plant (STP) was producing an average of $800 \mathrm{~m}^{3} /$ day biogas, used for lighting within the plant compounds, odor control system and lift for the digester equipment building, consequently complying with the sustainability principle [6]. It is a huge economical loss to neglect application of anaerobic digester for sewage treatment because this technology able to reduce sludge volume; by reducing of about $30 \%$ of the organic load (part of the solid organic matter is converted into gas) besides producing renewable energy (biogas) [7].

Despite the advantages of anaerobic digestion as mentioned above, the long retention time (typical 20-30 days) and less organic reduction were the major drawbacks of this anaerobic digestion. Appels [1] reported that organics reduction from sewage sludge through anaerobic digestion is limited to about $50 \%$ even after 20 days residence time. During the anaerobic digestion of complex organic matter, the hydrolysis is always the ratelimiting state. Therefore the optimization of the anaerobic digestion process strongly depends on the increase in hydrolysis efficiency [1, 8]. Moreover, the good contact between substrate and biomass is a crucial key in hydrolysis [9].

Pre-treatment is a method to improve hydrolysis, in which sewage sludge disintegration is achieved before entering the digester. In comparison with other methods of pretreatment, thermal pre-treatment has been considered to be a more promising technique [10, 11]. Most of the pre-treatments have only been applied to sewage secondary sludge (or waste activated sludge, WAS), due to the difficulty of sewage secondary sludge digestibility compared to sewage primary sludge. According to Jones [12], the gas yield (volume gas / volume sludge) from the digestion of WAS at 10 days solids retention time (SRT) is approximately four-fold lesser than what was observed from the digestion of primary sludge. Low thermal pre-treatment $\left(<100^{\circ} \mathrm{C}\right)$ was able to increase the solids and organic solubilisation of sewage sludge [13-16]. The higher organic soluble enhance the hydrolysis step consequently increased methane production [13, 17].

There are nine (9) options for energy recovery from sewage sludge (from the organic compounds in sewage sludge) including anaerobic digestion of sewage sludge, production of biofuels from sewage sludge, and direct production of electricity from sewage sludge in microbial fuel cells [18]. Biogas production is directly influenced by the type of sludge and the operating conditions of the digester. For a mixture of primary and secondary sludge the gas production amounts to approximately $1 \mathrm{~m}^{3}$ of biogas $/ \mathrm{kg}$ of organic solids biodegraded [4]. It is necessary to measure the composition of the sewage sludge to assess the options for energy recovery from sewage sludge as a sole substrate, particularly on the complex organic concentration. The pathway of the transformation of complex organic to biogas is established [19]. Therefore, the aim of this study was to characterize the domestic mixed sewage sludge and anaerobic biomass from the full-scale anaerobic digester particularly on the organic compounds, in which very few studies on this subject were reported. In addition, this study also investigated the impact of low thermal pre-treatment on the domestic mixed sewage sludge characteristics. 


\section{Material and Methods}

\subsection{Sample Collection}

Two types of sample were taken from the full-scale local anaerobic digester treating the domestic mixed sewage sludge located in Malaysia. The domestic mixed sewage sludge (DMS), which goes directly into the anaerobic digester and anaerobic biomass or anaerobically digested sludge (AnDS) were collected at each sampling day. AnDS was taken from the anaerobic digester itself. The sludge was stored at $4^{\circ} \mathrm{C}$ in the laboratory before use.

\subsection{Preparation for pre-thermally treated domestic mixed sewage sludge (DMS)}

After being stored at $4^{\circ} \mathrm{C}$ for a short time $(<24$ hours), the low thermal pre-treatment was applied to the DMS to investigate the effects of low thermal pre-treatment, particularly on organics solubilisation. Low thermal pre-treatment is expected to increase the organic solubilisation of domestic mixed sewage sludge.

The thermal pre-treatments were carried out using a thermostatic water bath operated at a temperature of $70^{\circ} \mathrm{C}$ and $90^{\circ} \mathrm{C}$ respectively. The procedures for preparing the prethermally treated DMS were described by Roslinda [20]. According to Salsabil, [21], the organic solubilisation $\left(\mathrm{S}_{\mathrm{X}}\right.$ in \%), can be calculated as below:

$$
S_{x}=\left(\frac{x_{s}-x_{s o}}{x_{P O}}\right) x 100 \%
$$

where,

$\mathrm{X}=$ represents either $\mathrm{COD}$, proteins or carbohydrates concentration.

$\mathrm{X}_{\mathrm{S}}=$ soluble concentration

$\mathrm{X}_{\mathrm{SO}}=$ initial soluble concentration

$\mathrm{X}_{\mathrm{PO}}=$ initial particulate concentration

\subsection{Analytical method}

Untreated DMS, pre-thermally treated DMS, and AnDS were analyzed for chemical oxygen demand, carbohydrate, and proteins. The analytical method for that parameter was described previously by Seswoya [22]. The sample for determination of the soluble concentration of chemical oxygen demand (COD), carbohydrates, and proteins were firstly centrifuged at $10000 \mathrm{rpm}$ for $10 \mathrm{~min}$, then filtered through a cellulose acetate filter of $0.45 \mu \mathrm{m}$ pore size prior to analysis $[23,24]$.

DR 6000 UV-Vis spectrophotometer, DRB200 Reactor (digester) and COD vial (TNT plus 822) were used for total and soluble COD determination, based on Reactor Digestion Method which was approved by USEPA.

\section{Results and Discussion}

\subsection{AnDS Characteristics}

Table 1 showed the ratios of soluble to particulate of each measured parameters. The ratios of soluble COD to total COD (SCOD/TCOD) were low. This was also observed for the 
AnDS originated from lab-scale continuous stirred tank reactor operated at mesophilic temperature $\left(37^{\circ} \mathrm{C}\right.$ and $\left.35^{\circ} \mathrm{C}\right)$ treating sewage sludge (mixed and waste activated sludge) $[25,26,15,16]$. AnDS also contained carbohydrates and proteins. AnDS from this study having higher protein than carbohydrate, which is opposite to what was observed by Lu [26] Astals [25] in which AnDS the in their study originated from lab-scale continuous stirred tank reactor. The lower concentration of soluble form of COD, carbohydrates, and proteins showed that the organics mostly existed in the form of a particulate. This was also observed by Astals [25] and Lu [26] previously.

Table 1. Soluble to total ratio of measured organic compounds in untreated AnDS

\begin{tabular}{|l|c|c|}
\hline \multirow{2}{*}{ Parameters } & \multicolumn{2}{|c|}{ Sampling date } \\
\cline { 2 - 3 } & $\mathbf{2 7 / 7 / 1 5}$ & $\mathbf{1 / 9 / 1 5}$ \\
\hline SCOD / TCOD & 0.14 & 0.09 \\
\hline SProteins / TProtein & 0.05 & 0.04 \\
\hline SCarbohydrate / TCarbohydrate & 0.03 & 0.05 \\
\hline
\end{tabular}

The data presented in the table were calculated from the average value from three sample

\subsection{DMS Characteristics}

The ratio of SCOD/TCOD ranged from 0.07 to 0.11 . In previous work of Astals [25], three different municipal mixed sewage sludge were having SCOD/TCOD equals to 0.07. $\mathrm{SCOD} / \mathrm{TCOD}$ value which is low as 0.04 was also observed from municipal mixed sewage sludge [27]. Proteins are higher in DMS than carbohydrates. The similar observation was observed when the municipal mixed sewage sludge and municipal secondary sewage sludge were studied $[10,21]$. However, this organic compounds existed in the form of particulate as shown by the low value of soluble to particulate ratios.

Table 2. Soluble to total ratio of measured organic compounds in untreated DMS

\begin{tabular}{|l|c|c|}
\hline \multirow{2}{*}{ Parameters } & \multicolumn{2}{c|}{ Sampling date } \\
\cline { 2 - 3 } & $\mathbf{2 7 / 7 / 1 5}$ & $\mathbf{1 / 9 / 1 5}$ \\
\hline SCOD / TCOD & 0.11 & 0.07 \\
\hline SProteins / TProteins & 0.03 & 0.02 \\
\hline SCarbohydrates / TCarbohydrates & 0.05 & 0.01 \\
\hline
\end{tabular}

The data presented in the table were calculated from the average value from three samples

\subsection{Pre-thermally treated DMS Characteristics}

Thermal treatment on DMS was performed for two different temperatures and several treatments period. An overview of the results is shown in Table 3. The thermal treatment released the monitored component to the water phase as indicated by the improved soluble to the total ratio as compared to the ratio from raw DMS at each sampling. The soluble COD was higher at $90^{\circ} \mathrm{C}$ compared to $70^{\circ} \mathrm{C}$, which is almost twofold, although the treatment period was $20 \mathrm{~min}$. Generally, the soluble COD and soluble carbohydrate were greater at the longer treatment time regardless the temperature. However, the highest values were observed at pre-treatment of $90^{\circ} \mathrm{C}$.

Applying Equation (1) to appropriate data (data not presented), the COD, proteins, and carbohydrates solubilisation were calculated as shown in Table 4. Fig. 1 showed the graphical illustration of organics solubilisation affected by the low thermal pre-treatment. At both temperatures $\left(70^{\circ} \mathrm{C}\right.$ and $\left.90^{\circ} \mathrm{C}\right)$, the solubilisation of COD and complex organics compounds were observed at each temperature. The gradually increased solubilisation was 
consistently observed for proteins at both pre-treatment conditions. Meanwhile, the carbohydrate solubilisation fluctuated at pre-treatment of $70^{\circ} \mathrm{C}$. The remarkable changes of carbohydrate solubilisation were observed at pre-treatment at $90^{\circ} \mathrm{C}$ compared to thermal treatment at $70^{\circ} \mathrm{C}$. The Amadori compounds or melanoidin as a result of the reactions of soluble carbohydrate with themselves or soluble protein was not observed in this study due to the pre-thermally DMS supernatant remained transparent and did not turn brown after treatment to form the Amadori compounds or melanoidins is not observed.

Table 3. Organic characteristics of pre-thermally treated DMS

\begin{tabular}{|c|c|c|c|c|c|c|}
\hline \multirow[b]{2}{*}{ Parameters } & \multicolumn{3}{|c|}{ Sampling date: $27 / 7 / 15$} & \multicolumn{3}{|c|}{ Sampling date: $1 / 9 / 15$} \\
\hline & $\begin{array}{l}\text { DMS } \\
7020\end{array}$ & $\begin{array}{l}\text { DMS } \\
7040\end{array}$ & $\begin{array}{c}\text { DMS } \\
7060\end{array}$ & $\begin{array}{l}\text { DMS } \\
9020\end{array}$ & $\begin{array}{l}\text { DMS } \\
9040\end{array}$ & $\begin{array}{l}\text { DMS } \\
9060\end{array}$ \\
\hline $\begin{array}{l}\text { Total COD, } \\
\text { TCOD }(\mathrm{g} / \mathrm{L})\end{array}$ & $\begin{array}{l}9.61 \pm \\
0.05\end{array}$ & $\begin{array}{c}8.83 \pm \\
0.11\end{array}$ & $\begin{array}{c}7.35 \pm \\
0.00\end{array}$ & $\begin{array}{c}16.30 \pm \\
0.07\end{array}$ & $\begin{array}{c}20.60 \pm \\
0.00\end{array}$ & $\begin{array}{c}17.78 \pm \\
0.10\end{array}$ \\
\hline $\begin{array}{l}\text { Soluble COD, } \\
\text { SCOD }(\mathrm{g} / \mathrm{L})\end{array}$ & $\begin{array}{c}1.95 \pm \\
0.07 \\
\end{array}$ & $\begin{array}{c}1.84 \pm \\
0.00 \\
\end{array}$ & $\begin{array}{c}1.57 \pm \\
0.00 \\
\end{array}$ & $\begin{array}{c}3.32 \pm \\
0.01 \\
\end{array}$ & $\begin{array}{c}3.48 \pm \\
0.01 \\
\end{array}$ & $\begin{array}{c}3.69 \pm \\
0.00 \\
\end{array}$ \\
\hline SCOD / TCOD & 0.20 & 0.21 & 0.21 & 0.20 & 0.17 & 0.21 \\
\hline $\begin{array}{l}\text { Total Proteins, } \\
\text { TProteins } \\
(\mathrm{mg} / \mathrm{L})\end{array}$ & $\begin{array}{l}3850.33 \\
\pm 124.03\end{array}$ & $\begin{array}{l}3138.33 \\
\pm 45.79\end{array}$ & $\begin{array}{l}2625.00 \\
\pm 91.02\end{array}$ & $\begin{array}{c}2532.50 \\
\pm 1.73\end{array}$ & $\begin{array}{l}3007.00 \\
\pm 38.16\end{array}$ & $\begin{array}{l}2257.33 \\
\pm 33.39\end{array}$ \\
\hline $\begin{array}{l}\text { Soluble Proteins } \\
\text { SProtein } \\
(\mathrm{mg} / \mathrm{L})\end{array}$ & $\begin{array}{c}467.80 \pm \\
2.13\end{array}$ & $\begin{array}{c}548.97 \pm \\
6.32\end{array}$ & $\begin{array}{c}545.65 \pm \\
6.03\end{array}$ & $\begin{array}{l}457.63 \\
\pm 2.91\end{array}$ & $\begin{array}{c}500.52 \pm \\
0.06\end{array}$ & $\begin{array}{c}556.48 \pm \\
2.95\end{array}$ \\
\hline SProteins / TProteins & 0.12 & 0.17 & 0.21 & 0.18 & 0.17 & 0.25 \\
\hline $\begin{array}{l}\text { Total Carbohydrates, } \\
\text { TCarbohydrates } \\
(\mathrm{mg} / \mathrm{L})\end{array}$ & $\begin{array}{c}281.83 \pm \\
6.53\end{array}$ & $\begin{array}{c}271.17 \pm \\
6.81\end{array}$ & $\begin{array}{c}48.67 \pm \\
0.29\end{array}$ & $\begin{array}{c}780.50 \pm \\
7.81\end{array}$ & $\begin{array}{l}1246.00 \\
\pm 23.26\end{array}$ & $\begin{array}{c}917.00 \pm \\
3.28\end{array}$ \\
\hline $\begin{array}{l}\text { Soluble Carbohydrates, } \\
\text { SCarbohydrates, } \\
(\mathrm{mg} / \mathrm{L})\end{array}$ & $\begin{array}{c}8.62 \pm \\
0.41\end{array}$ & $\begin{array}{c}38.75 \pm \\
0.33\end{array}$ & $\begin{array}{c}23.00 \pm \\
0.33\end{array}$ & $\begin{array}{c}125.65 \pm \\
3.96\end{array}$ & $\begin{array}{c}128.02 \pm \\
0.56\end{array}$ & $\begin{array}{c}136.57 \pm \\
2.24\end{array}$ \\
\hline $\begin{array}{l}\text { SCarbohydrates / } \\
\text { TCarbohydrates }\end{array}$ & 0.03 & 0.14 & 0.47 & 0.16 & 0.10 & 0.15 \\
\hline
\end{tabular}

1) DMS 7020 is referring to the domestic mixed sewage sludge treated at $70^{\circ} \mathrm{C}$ for 20 minutes. Using this description all the sample were labeled accordingly.

2) DMS 9020 is referring to the domestic mixed sewage sludge treated at $90^{\circ} \mathrm{C}$ for 20 minutes. Using this description all the sample were labeled accordingly.

3) $9.61 \pm 0.05=$ average \pm stdev.

4) The coefficient of variation $(\mathrm{CV})$ for each data is less than $5 \%$. $(\mathrm{CV}<5 \%)$

At treatment time of $60 \mathrm{~min}$ at $90^{\circ} \mathrm{C}$, protein solubilisation has exceeded $14 \%$. Meanwhile at similar treatment time at $70^{\circ} \mathrm{C}$, protein solubilisation reduced almost $5 \%$. The COD solubilisation seem to be low at the temperature of $70^{\circ} \mathrm{C}$ even after the treatment time increased to $60 \mathrm{~min}$. This was not observed for COD solubilisation of thermal treatment at $90^{\circ} \mathrm{C}$. On contrary, the COD solubilisation increased gradually over the treatment time. 
Table 4. Organics solubilisation

\begin{tabular}{|c|c|c|c|c|c|c|c|}
\hline \multirow{2}{*}{\multicolumn{2}{|c|}{$\begin{array}{l}\text { Sampling Date } \\
\text { Sample ID }\end{array}$}} & \multicolumn{3}{|c|}{$27 / 7 / 15$} & \multicolumn{3}{|c|}{$1 / 9 / 15$} \\
\hline & & \multirow{2}{*}{$\begin{array}{l}\text { DMS } \\
\mathbf{7 0 2 0} \\
8.90\end{array}$} & \multirow{2}{*}{$\begin{array}{l}\text { DMS } \\
\mathbf{7 0 4 0} \\
7.77\end{array}$} & \multirow{2}{*}{$\begin{array}{c}\text { DMS } \\
\mathbf{7 0 6 0} \\
5.01\end{array}$} & \multirow{2}{*}{$\begin{array}{l}\text { DMS } \\
\mathbf{9 0 2 0} \\
7.55\end{array}$} & \multirow{2}{*}{$\begin{array}{l}\text { DMS } \\
\mathbf{9 0 4 0} \\
8.26\end{array}$} & \multirow{2}{*}{$\begin{array}{l}\text { DSS } \\
\mathbf{9 0 6 0} \\
9.18\end{array}$} \\
\hline . & COD & & & & & & \\
\hline$\tilde{0}$ & Carbohydrates & -2.82 & 4.37 & 0.61 & 8.75 & 8.94 & 9.62 \\
\hline i & Proteins & 8.40 & 10.34 & 10.26 & 12.49 & 13.80 & 15.52 \\
\hline
\end{tabular}

1) DMS 7020 is referring to the domestic mixed sewage sludge treated at $70^{\circ} \mathrm{C}$ for 20 minutes. Using this description all the sample were labeled accordingly.

2) DMS 9020 is referring to the domestic mixed sewage sludge treated at $90^{\circ} \mathrm{C}$ for 20 minutes. Using this description all the sample were labeled accordingly.

3) All date presented in the table are calculated using average data.

4) The solubilisation in negative is showing that the soluble concentration of monitored parameter is less than what was observed from the non-treated sample.
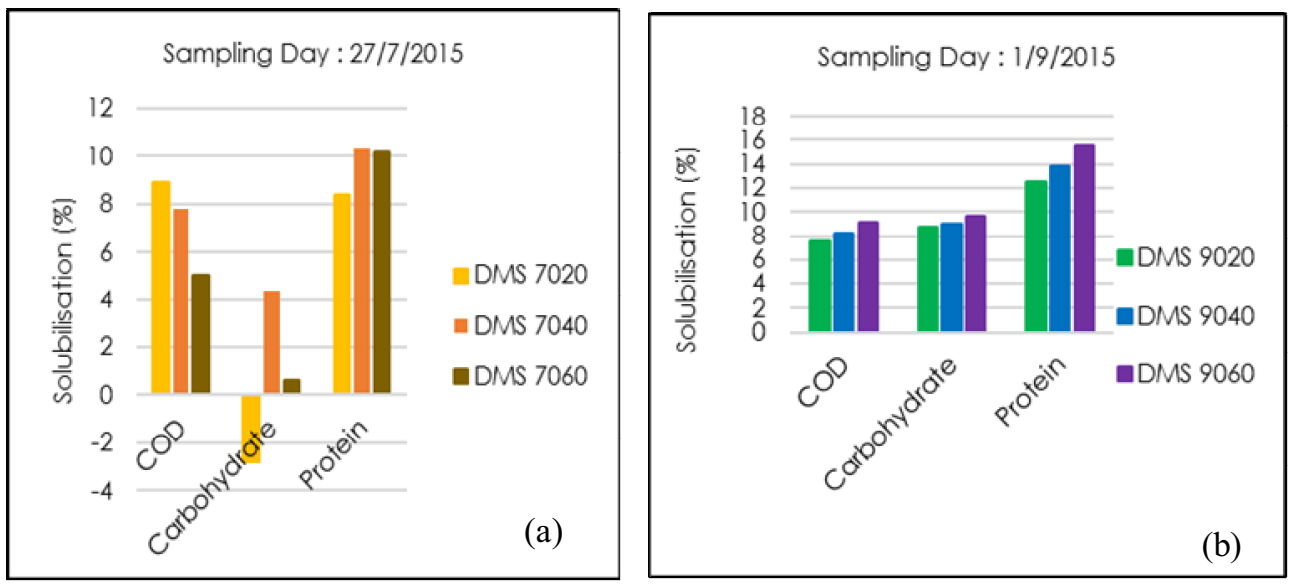

Fig. 1. Solubilisation Changes due to low thermal pre-treatment a) $70^{\circ} \mathrm{C}$ and b) $90^{\circ} \mathrm{C}$

\section{Conclusions}

The present paper studied the characteristics of AnDS and DMS originated from full-scale anaerobic digester treating domestic mixed sewage sludge. It was seen that the AnDS also contained carbohydrates and protein, less than what was observed in DMS. Generally, the treatment operations and conditions would influence the characteristics of DMS and AnDS. The paper also presented the studies of the application of low temperatures $\left(70^{\circ} \mathrm{C}\right.$ and $\left.90^{\circ} \mathrm{C}\right)$ as a pre-treatment method, to improve the hydrolysis prior to anaerobic digestion of domestic mixed sewage sludge. Generally, the organic solubilisation was observed after 20 min treatment time at each temperature except for carbohydrate. However, the organic compounds are solubilised efficiently during thermal pre-treatment at $90^{\circ} \mathrm{C}$. As for thermal treatment at $90^{\circ} \mathrm{C}$, more soluble organic compounds released at the higher treatment time. This finding suggested that the thermal pre-treatment at low temperature able to improve the organic solubilisation. However, in future work, pre-thermally treated DMS (with improved organic solubilisation) will acted as a substrate for anaerobic digestion, in which the energy recovery will be estimated. 
The authors wish to express their gratitude to Universiti Tun Hussein Onn Malaysia (UTHM) for providing financial support and to R\&D and Innovation Unit, Indah Water Konsortium (IWK) for their technical support.

\section{References}

[1] L. Appels, J. Baeyens, J. Degrève, and R. Dewil, Principles and Potential of The Anaerobic Digestion of Waste-Activated Sludge, Prog. Energy Combust. Sci., 34(6), 755-781, (2008)

[2] M. B. Ridzuan, Z. Daud, A. A. Abdul Latiff, Z. Ahmad and Z. Zakariah, Landfill Leachate Treatment Using Hybrid Up-Flow Anaerobic Sludge Blanket ( HUASB ) Reactor, Int. J. Integr. Eng., 5(1), pp. 8-13, (2013)

[3] C. Arnaiz, J. C. Gutierrez and J. Lebrato, Biomass stabilization in the anaerobic digestion of wastewater sludges, Bioresour. Technol., 97(10), 1179-1184, (2006)

[4] A.S. Muhamad Izham, A. Chrisnawan, M. Brown-Santirso, E.T. Gelindon, A. Kabalinskiy, L.M. Juan Roberto, T. Otsuki and M.O. Sinocruz, APEC Energy Demand And Supply Outlook 6th Edition, Vol. 1, Asia Pacific Energy Research Centre, Tokyo, (2016)

[5] P. Kumaran, D. Hephzibah, R. Sivasankari, N. Saifuddin and A.H. Shamsuddin, A review on industrial scale anaerobic digestion systems deployment in Malaysia: Opportunities and challenges, Renew. Sustain. Energy Rev., 56, 929-940, (2016)

[6] Indah Water Konsortium Sdn Bhd, "Cleaning the Unseen For a Sustainable Future, Sustainable Report 2012-2013, (2013)

[7] E. Farno, J.C. Baudez, R. Parthasarathy and N. Eshtiaghi, Rheological characterisation of thermally-treated anaerobic digested sludge: impact of temperature and thermal history, Water Res., 56, 156-61, (2014)

[8] W. Lv, F.L. Schanbacher and Z. Yu, Putting Microbes to Work in Sequence: Recent Advances in Temperature-Phased Anaerobic Digestion Processes, Bioresour. Technol., 101(24), 9409-14, (2010)

[9] I. Angelidaki and W. Sanders, Assessment of the anaerobic biodegradability of macropollutants, Rev. Environ. Sci. Bio/Technology, 3(2), 117-129, (2004)

[10] S. Ponsá, I. Ferrer, F. Vázquez and X. Font, Optimization of the hydrolytic-acidogenic anaerobic digestion stage (55 degrees $\mathrm{C}$ ) of sewage sludge: influence of $\mathrm{pH}$ and solid content., Water Res., 42(14), 3972-80, (2008)

[11] W.J. Park and J.H. Ahn, Effects of Microwave Pretreatment on Mesophilic Anaerobic Digestion for Mixture of Primary and Secondary Sludges Compared with Thermal Pretreatment, Environ. Eng. Res., 16(2), 103-109,(2011)

[12]R. Jones, W. Parker, Z. Khan, S. Murthy and M. Rupke, Characterization of sludges for predicting anaerobic digester performance., Wat. Sci.Tech, 57(5), 721-726, (2008)

[13]L. Appels, J. Degrève, B. Van der Bruggen, J. Van Impe and R. Dewil, Influence of low temperature thermal pre-treatment on sludge solubilisation, heavy metal release and anaerobic digestion, Bioresour. Technol., 101(15), 5743-8, (2010)

[14]I. A. Nges and J. Liu, Effects of anaerobic pre-treatment on the degradation of dewatered-sewage sludge, Renew. Energy, 34(7), 1795-1800, (2009)

[15]I. Ferrer, S. Ponsá, F. Vázquez and X. Font, Increasing biogas production by thermal $\left(70^{\circ} \mathrm{C}\right)$ sludge pre-treatment prior to thermophilic anaerobic digestion, Biochem. Eng. J., 42(2), 186-192, (2008) 
[16]I. V Skiadas, H. N. Gavala, J. Lu and B. K. Ahring, Thermal pre-treatment of primary and secondary sludge at 70 degrees $\mathrm{C}$ prior to anaerobic digestion., Water Sci. Technol., 52(1-2), 161-166, (2005)

[17] Y. Yan, H. Chen, W. Xu, Q. He and Q. Zhou, Enhancement of Biochemical Methane Potential from Excess Sludge with Low Organic Content by Mild Thermal Pretreatment, Biochem. Eng. J., 70, 127-134, (2013)

[18]W. Rulkens, Sewage Sludge as a Biomass Resource for the Production of Energy: Overview and Assessment of the Various Options, Energy and Fuels, 22, 9-15, (2008)

[19]W. Gujer and A. J. B. Zehnder, Conversion Process of Anaerobic Digestion, Wat.Sci.Tech, 15, 127-167, (1983)

[20]R. Seswoya and A. T. Abdul Karim, Low Thermal Pretreatment as Method for Increasing the Bioavailability of Organic Matters in Domestic Mixed Sludge, Int. Conf. on Civil and Env. Eng. for Sustanability (IConCESS 2015), (2016)

[21] M. R. Salsabil, J. Laurent, M. Casellas and C. Dagot, Techno-economic evaluation of thermal treatment, ozonation and sonication for the reduction of wastewater biomass volume before aerobic or anaerobic digestion, J. Hazard. Mater., 174, 323-33, (2010)

[22]R. Seswoya and A.T. Abdul Karim, Characterization Of Organic Matter Solubilisation For Domestic Sewage Sludge Before And After Thermal Pretreatment At 700 C, Int. J. Appl. Eng. Res., 10(95), 21-25, (2015)

[23]C. A. Wilson and J. T. Novak, Hydrolysis of Macromolecular Components of Primary and Secondary Wastewater Sludge by Thermal Hydrolytic Pretreatment, Water Res., 43(18), 4489-98, (2009)

[24]H. Yi, Y. Han and Y. Zhuo, Effect of Combined Pretreatment of Waste Activated Sludge for Anaerobic Digestion Process, Procedia Environ. Sci., 18, 716-721, (2013)

[25]S. Astals, M. Esteban-Gutiérrez, T. Fernández-Arévalo, E. Aymerich, J. L. GarcíaHeras and J. Mata-Alvarez, Anaerobic digestion of seven different sewage sludges: A biodegradability and modelling study, Water Res., 47(16), 1-11, (2013)

[26]X. Lu, G. Zhen, Y. Liu, T. Hojo, A. L. Estrada and Y.-Y. Li, Long-term effect of the antibiotic cefalexin on methane production during waste activated sludge anaerobic digestion, Bioresour. Technol., 169, 644-51, (2014)

[27]A. S. Ucisik and M. Henze, Biological hydrolysis and acidification of sludge under anaerobic conditions: the effect of sludge type and origin on the production and composition of volatile fatty acids, Water Res., 42(14), 3729-38, (2008) 